\title{
Two point-of-care test-based approaches for the exclusion of deep vein thrombosis in general practice: a cost-effectiveness analysis
}

Jorn Heerink ( $\boldsymbol{D}$ j.s.heerink@utwente.nl )

University of Twente

Ruud Oudega

Jeroen Bosch Hospital

Hendrik Koffijberg

University of Twente

Ron Kusters

University of Twente

Joanne Nies

GGD Twente

Michelle Kip

University of Twente

\section{Research Article}

Keywords: Deep Vein Thrombosis (DVT), cost-effectiveness analysis, point-of-care test (POCT), General Practitioner (GP), general practice, D-dimer, clinical decision rule (CDR), DVT care pathway

Posted Date: January 18th, 2022

DOI: https://doi.org/10.21203/rs.3.rs-1160342/v1

License: (c) (1) This work is licensed under a Creative Commons Attribution 4.0 International License. Read Full License 


\section{Abstract \\ Background}

In the diagnostic work-up of deep vein thrombosis (DVT), the use of point-of-care-test (POCT) D-dimer assays is emerging as a promising patient-friendly alternative to regular D-dimer assays, but their costeffectiveness is unknown. We compared the cost-effectiveness of two POCT-based approaches to the most common, laboratory-based, situation.

\section{Methods}

A patient-level simulation model was developed to simulate the diagnostic trajectory of patients presenting with symptoms of DVT at the general practitioner (GP). Three strategies were defined for further diagnostic work-up: one based on current guidelines ('regular strategy') and two alternative approaches where a POCT for D-dimer is implemented at the 1) phlebotomy service ('DVT care pathway') and 2) GP practice ('fast-POCT strategy'). Probabilities, costs and health outcomes were obtained from the literature. Costs and effects were determined from a societal perspective over a time horizon of six months. Uncertainty in model outcomes was assessed with a one-way sensitivity analysis.

\section{Results}

The Quality-Adjusted Life Years (QALYs) scores for the three DVT diagnostic work-up strategies were all around 0.43 across a six month-time horizon. Cost-savings of the two POCT-based strategies compared to the regular strategy were $€ 103 /$ patient for the DVT care pathway ( $95 \% \mathrm{Cl}$ : $€ 117-89$ ), and $€ 87 /$ patient for the fast-POCT strategy (95\% Cl: -€113-67).

\section{Conclusions}

Point-of-care-based approaches result in similar health outcomes compared with regular strategy. Given their expected cost-savings and patient-friendly nature, we recommend implementing a D-dimer POCT device in the diagnostic DVT work-up.

\section{Background}

Annually, 1-2 per 1000 persons suffer from deep vein thrombosis (DVT) making it the third most prevalent cardiovascular disease according to an extensive Canadian study $(1,2)$. Deep vein thrombosis is associated with short and long-term morbidity and mortality, and recurrence of DVT episodes is common. Severe complications such as pulmonary embolism (PE) or post-thrombotic syndrome (PTS) can occur $(3,4)$; these are known to reduce quality of life $(5,6)$. Hence, appropriate disease detection is vital to timely initiating effective treatment possibilities. These include oral anticoagulation, in some cases 
preceded by heparin injections, and compression stockings, depending on the symptoms and other patient characteristics.

As DVT cannot be discriminated from other diseases based on clinical judgment alone, in the Netherlands a specific diagnostic DVT work-up is initiated when a general practitioner (GP) suspects a DVT. A clinical decision rule $(C D R)$ is initially applied to discriminate low $(C D R<4)$ from high $(C D R \geq 4)$ risk patients (Table 1 ).

Table 1

Clinical decision rule for deep vein thrombosis according to the Dutch Committee of General Practitioners (7)

\begin{tabular}{|llc|}
\hline \multicolumn{2}{|l|}{ Risk factors } & Weight \\
\hline 1. & Male gender & 1 \\
\hline 2. & $\begin{array}{l}\text { Use of systemic estrogens (such as contraceptive pills, hormone rings/patches or } \\
\text { needles) }\end{array}$ & 1 \\
\hline 3. & Presence of malignancy & 1 \\
\hline 4. & Surgery in the last month & 1 \\
\hline 5. & Absence of trauma explaining swelling in the calf & 1 \\
\hline 6. & Expanded veins of the limb & 1 \\
\hline 7. & Difference in maximal calf size $\geq 3 \mathrm{~cm}$ & 2 \\
\hline
\end{tabular}

High-risk patients immediately undergo a compression ultrasonography (CUS) in the hospital, while a laboratory test (D-dimer) is performed in low-risk patients. A negative (non-elevated) D-dimer rules out DVT, obviating the need for performing a relatively expensive CUS (8-10).

Deviations from this approach occur in current practice for a number of reasons. A recent publication reported that a CDR is correctly applied by $79.3 \%$ of Dutch GPs; this can be explained by the use of empirical probability estimates ('gestalt') as an alternative for CDRs $(11,12)$. Sensitivity of gestalt as a screening tool appears to be similar, but the specificity is substantially decreased compared to a CDRbased approach, leading to unnecessary referrals and an increase in health care costs $(13,14)$. Another deviation to the standard approach arises when results of a laboratory D-dimer assay are expected to be received after GP working hours. In these cases, patients are referred directly to the radiology or emergency department, causing unnecessary health care expenditures and discomfort of patients (15); $98.6 \%$ of patients assigned a low CDR score did not have DVT (8).

These undesirable phenomena could be avoided by introducing a point-of-care test (POCT) for D-dimer analysis carried out on low-risk patients. Point-of-care devices can be located at a phlebotomy service to accelerate diagnostic work-up. Patients with positive (elevated) D-dimer results are directly referred to undergo a CUS, while patients with a low CDR and negative POCT D-dimer test are discharged without 
further involving the GP. As an upcoming alternative, novel quantitative capillary (whole-blood) POCT Ddimer assays could be positioned in the GP practice, requiring only a finger-prick instead of a venipuncture, providing results in less than 15 minutes (16). To our knowledge, the impact of both POCT strategies on health outcomes and costs, remains unknown. We therefore assessed the costeffectiveness of two POCT-based approaches, comparing them to the most common, laboratory-based, situation in the Netherlands.

\section{Methods}

\section{Model description}

We developed a patient-level simulation model in Microsoft Excel (version 16.0.14228.20288). It represents the diagnostic pathways of patients with symptoms of DVT from the moment of presentation at the GP until the (correct) diagnosis is established. We applied this health-economic model to analyze the cost-effectiveness of two POCT-based approaches compared to the most common, laboratory-based, situation. Data for the input parameters was obtained from the literature. The outcome measures are the incremental costs, the incremental health effects expressed in Quality-Adjusted Life Years (QALYs), and if these are non-negligible, the incremental cost-effectiveness ratio (ICER) for the two POCT-based approaches compared to the laboratory-based situation.

\section{Diagnostic strategies}

Three different strategies of diagnosing DVT in primary care in the Netherlands were defined. An overview of these strategies is given in figure 1 .

\section{(Separate file) Figure 1}

Schematic overview of diagnostic strategies of suspected deep venous thrombosis.

$C D R=$ clinical decision rule, CUS: compression ultrasonography, $D+=$ Disease present,$D-=$ Disease absent, $D V T=$ Deep venous thrombosis, $G P=$ General practitioner, $P O C T=$ Point-of-care test,$T+=$ test with positive result after D-dimer assay or CUS, $T$ - = negative test result after D-dimer assay or CUS.

The regular strategy -the laboratory-based situation- is based on the Dutch College of General Practitioners policy guidelines. These recommend that a CDR and a subsequent quantitative D-dimer assay should be used to rule out DVT (17). In addition, we took into consideration whether the laboratory D-dimer result would be received during normal GP business hours. If so, only in case of a positive Ddimer would the patient be referred to undergo a CUS, as DVT is directly ruled-out if the D-dimer result is negative. However, should the result not be on time, the patient would be directly referred to undergo a CUS without a preceding laboratory D-dimer assay.

In an alternative approach, the DVT care pathway, patients are referred to the phlebotomy service at the hospital if, based on their CDR score, they are categorized as low risk. A quantitative D-dimer assay is 
then performed on a POCT device present at the phlebotomy service. If the D-dimer results are positive, patients will directly undergo a CUS. Accordingly, the radiologist will, depending on the results, refer the patient to the internist without intervention of the GP. Those with a negative D-dimer are discharged and left to the attention of the GP.

A third strategy involves the introduction of a POCT D-dimer device at the GP practice; this approach is referred hereafter as the fast-POCT strategy. If the patient is categorized as low-risk according to the CDR score, the GP determines the patient's D-dimer value during the consultation. If the D-dimer value is positive, the patient is referred to undergo a CUS; if negative, the patient is discharged.

In all three strategies GPs can deviate from the current guidelines and may or may not apply the CDR. Given that some GPs may choose not to use a CDR, we also accounted for this scenario.

\section{Model inputs}

Of patients presenting at the GP with suspected DVT, $38.4 \%$ are male with an average age of $56.9(8,10$, $18,19)$. In our model we assumed that $79.3 \%$ of GPs correctly apply a CDR $(11)$. On the basis that patients arriving after $13: 00 \mathrm{~h}$ are directly referred for a CUS, we assumed that $70.8 \%$ of patients would arrive in time for a laboratory D-dimer assay (20-23). The probabilities of a positive or negative D-dimer test or CUS result were obtained from multiple studies $(8,14,18,19,24-26)$. A weighted estimate of sensitivity (Sn) and specificity (Sp) was obtained from a series of POCT and laboratory D-dimer assays in order to get a representative performance estimate of these two D-dimer assays $(16,24,27-30)$.

Quality adjusted life years were used as effectiveness outcome. The health states incorporated in the model were: healthy, suffering from DVT, suffering from DVT complicated by PTS, PE, major bleeding or recurrence $(5,31-34)$. As a patient can only have a maximum of one quality of life score per year, the maximum per half year, and thus the upper limit of the $95 \% \mathrm{Cl}$, was set at 0.5 .

In accordance with the Dutch costing manual, we considered all costs from a societal perspective. These start from the moment a patient arrives at a GP until (correct) diagnosis up to six months of anticoagulant treatment or the occurrence of potential complications. Costs of both office and phone consultations were obtained from the Dutch costing manual (35). Diagnostic costs from a blood draw, a laboratory D-dimer test and a CUS were derived from the Dutch Health Care Authority (20). Procurement costs of a POCT device and prices per test were retrieved from sales brochures and retailers. We also included travel and parking costs (20). The number of production hours lost due to (diagnosing) DVT and potential complications were derived from literature and were both based on age group, gender and the net labor participation $(17,32,36,37)$. These were then multiplied by the costs per production hour lost determined based on the net labor participation classified per gender and age group of Dutch society (17). To determine treatment costs and costs of potential complications, we derived an average from the literature $(20,38-41)$. The cost estimation was then converted to 2021 Euros based on the Dutch consumer price index, (42). 
An overview of the model input parameters for each of the three patient strategies used in the model, costs and quality of life score (i.e., utility values) with their corresponding Cls can be found in Tables 2, 3 and 4, respectively. Assumptions for the model are provided as supplementary material. 
Table 2: Model input parameters for strategies used, showing the parameter, the value (probability) used in the model, the $95 \% \mathrm{Cl}$ interval, the distribution used and the data source.

\begin{tabular}{|c|c|c|c|c|c|c|}
\hline $\begin{array}{l}\text { Model input } \\
\text { parameters }\end{array}$ & Category & $\begin{array}{l}\text { Prob- } \\
\text { ability }\end{array}$ & $\begin{array}{l}\text { Lower } \\
\text { limit } \\
95 \% \mathrm{Cl}\end{array}$ & $\begin{array}{l}\text { Upper } \\
\text { limit } \\
95 \% \mathrm{Cl}\end{array}$ & $\begin{array}{l}\text { Distri- } \\
\text { bution }\end{array}$ & $\begin{array}{l}\text { Refer- } \\
\text { ence }\end{array}$ \\
\hline $\begin{array}{l}\text { Patient } \\
\text { Demographics }\end{array}$ & Sex (male) & $38.4 \%$ & $37.0 \%$ & $39.8 \%$ & Beta & $\begin{array}{l}(10,46- \\
48)\end{array}$ \\
\hline \multirow[t]{6}{*}{ Age group } & $<34$ & $9.8 \%$ & $8.9 \%$ & $10.6 \%$ & Dirichlet & $\begin{array}{l}(10,46- \\
48)\end{array}$ \\
\hline & $35-44$ & $14.3 \%$ & $13.3 \%$ & $15.4 \%$ & Dirichlet & $\begin{array}{l}(10,46- \\
48)\end{array}$ \\
\hline & $45-54$ & $21.5 \%$ & $20.3 \%$ & $22.7 \%$ & Dirichlet & $\begin{array}{l}(10,46- \\
48)\end{array}$ \\
\hline & $55-64$ & $26.9 \%$ & $25.7 \%$ & $28.2 \%$ & Dirichlet & $\begin{array}{l}(10,46- \\
48)\end{array}$ \\
\hline & $65-75$ & $11.9 \%$ & $11.0 \%$ & $12.8 \%$ & Dirichlet & $\begin{array}{l}(10,46- \\
48)\end{array}$ \\
\hline & $>75$ & $15.5 \%$ & $14.5 \%$ & $16.5 \%$ & Dirichlet & $\begin{array}{l}(10,46- \\
48)\end{array}$ \\
\hline Probability DVT & Prevalence DVT & $15.8 \%$ & $14.2 \%$ & $17.4 \%$ & Beta & $(12,24,46)$ \\
\hline \multirow[t]{2}{*}{ CDR } & GP applies CDR & $79.3 \%$ & $76.7 \%$ & $81.8 \%$ & Beta & (11) \\
\hline & $\mathrm{CDR} \geq 4$ & $42.6 \%$ & $40.4 \%$ & $44.8 \%$ & Beta & $(12,24,46)$ \\
\hline Arrival patient at GP & $\begin{array}{l}\text { Arrival patient } \\
\text { before 13:00h }\end{array}$ & $70.8 \%$ & $33.1 \%$ & $100.0 \%$ & Beta & $\begin{array}{l}(1,21- \\
23,49)\end{array}$ \\
\hline \multirow[t]{7}{*}{$\begin{array}{l}\text { Regular strategy } \\
\text { (CDR not applied) }\end{array}$} & $\begin{array}{l}\text { Prevalence DVT } \\
\text { regular CUS }\end{array}$ & $15.8 \%$ & $14.2 \%$ & $17.4 \%$ & Beta & $(12,24,46)$ \\
\hline & $\begin{array}{l}\text { Sensitivity regular } \\
\text { CUS }\end{array}$ & $93.8 \%$ & $81.9 \%$ & $100.0 \%$ & Beta & $(12,24,46)$ \\
\hline & $\begin{array}{l}\text { Specificity regular } \\
\text { CUS }\end{array}$ & $97.8 \%$ & $94.7 \%$ & $100.0 \%$ & Beta & $(12,24,46)$ \\
\hline & $\begin{array}{l}\text { Prevalence DVT } \\
\text { regular D-di }\end{array}$ & $15.8 \%$ & $14.2 \%$ & $17.4 \%$ & Beta & $(12,24,46)$ \\
\hline & $\begin{array}{l}\text { Sensitivity regular } \\
\text { D-di }\end{array}$ & $97.9 \%$ & $90.9 \%$ & $100.0 \%$ & Beta & $(12,24,46)$ \\
\hline & $\begin{array}{l}\text { Specificity regular } \\
\text { D-di }\end{array}$ & $54.2 \%$ & $43.6 \%$ & $64.9 \%$ & Beta & $(12,24,46)$ \\
\hline & $\begin{array}{l}\text { Prevalence DVT } \\
\text { regular CUS after } \\
\text { D-di }\end{array}$ & $28.6 \%$ & $16.5 \%$ & $40.6 \%$ & Beta & $(12,24,46)$ \\
\hline
\end{tabular}


Table 2: Model input parameters for strategies used, showing the parameter, the value (probability) used in the model, the $95 \% \mathrm{Cl}$ interval, the distribution used and the data source.

\begin{tabular}{|c|c|c|c|c|c|c|}
\hline & $\begin{array}{l}\text { Sensitivity regular } \\
\text { CUS after D-di }\end{array}$ & $93.8 \%$ & $81.8 \%$ & $100.0 \%$ & Beta & $(12,24,46)$ \\
\hline & $\begin{array}{l}\text { Specificity regular } \\
\text { CUS after D-di }\end{array}$ & $97.8 \%$ & $93.2 \%$ & $100.0 \%$ & Beta & $(12,24,46)$ \\
\hline \multirow{6}{*}{$\begin{array}{l}\text { POCT-based } \\
\text { approaches (CDR } \\
\text { not applied) }\end{array}$} & $\begin{array}{l}\text { Prevalence DVT } \\
\text { CUS }\end{array}$ & $35.7 \%$ & $21.1 \%$ & $50.4 \%$ & Beta & $(12,24,46)$ \\
\hline & Sensitivity CUS & $93.8 \%$ & $81.5 \%$ & $100.0 \%$ & Beta & $(12,24,46)$ \\
\hline & Specificity CUS & $97.8 \%$ & $92.2 \%$ & $100.0 \%$ & Beta & $(12,24,46)$ \\
\hline & $\begin{array}{l}\text { Prevalence DVT D- } \\
\text { di }\end{array}$ & $15.8 \%$ & $14.2 \%$ & $17.4 \%$ & Beta & $(12,24,46)$ \\
\hline & Sensitivity D-di & $93.2 \%$ & $80.5 \%$ & $100.0 \%$ & Beta & $(12,24,46)$ \\
\hline & Specificity D-di & $68.6 \%$ & $58.7 \%$ & $78.5 \%$ & Beta & $(12,24,46)$ \\
\hline \multirow[t]{9}{*}{$\begin{array}{l}\text { Regular strategy } \\
\text { (CDR applied) }\end{array}$} & $\begin{array}{l}\text { Prevalence DVT } \\
>13: 00 \mathrm{~h} \text { CUS }\end{array}$ & $3.8 \%$ & $2.7 \%$ & $4.9 \%$ & Beta & $(12,24,46)$ \\
\hline & $\begin{array}{l}\text { Sensitivity }>13: 00 h \\
\text { CUS }\end{array}$ & $93.8 \%$ & $69.5 \%$ & $100.0 \%$ & Beta & $(12,24,46)$ \\
\hline & $\begin{array}{l}\text { Specificity }>13: 00 h \\
\text { CUS }\end{array}$ & $97.8 \%$ & $94.9 \%$ & $100.0 \%$ & Beta & $(12,24,46)$ \\
\hline & $\begin{array}{l}\text { Prevalence DVT } \\
<13: 00 \mathrm{~h} \text { D-di }\end{array}$ & $3.8 \%$ & $2.7 \%$ & $4.9 \%$ & Beta & $(12,24,46)$ \\
\hline & $\begin{array}{l}\text { Sensitivity }<13: 00 h \\
\text { D-di }\end{array}$ & $97.9 \%$ & $83.7 \%$ & $100.0 \%$ & Beta & $(12,24,46)$ \\
\hline & $\begin{array}{l}\text { Specificity <13:00h } \\
\text { D-di }\end{array}$ & $54.2 \%$ & $44.3 \%$ & $64.2 \%$ & Beta & $(12,24,46)$ \\
\hline & $\begin{array}{l}\text { Prevalence DVT } \\
<13: 00 \text { h CUS after } \\
\text { D-dim }\end{array}$ & $7.8 \%$ & $6.2 \%$ & $9.3 \%$ & Beta & $(12,24,46)$ \\
\hline & $\begin{array}{l}\text { Sensitivity < } 13: 00 \mathrm{~h} \\
\text { CUS after D-dim }\end{array}$ & $93.8 \%$ & $69.3 \%$ & $100.0 \%$ & Beta & $(12,24,46)$ \\
\hline & $\begin{array}{l}\text { Specificity < } 13: 00 \mathrm{~h} \\
\text { CUS after D-dim }\end{array}$ & $97.8 \%$ & $93.5 \%$ & $100.0 \%$ & Beta & $(12,24,46)$ \\
\hline \multirow{2}{*}{$\begin{array}{l}\text { POCT-based } \\
\text { approaches (CDR } \\
\text { applied) }\end{array}$} & $\begin{array}{l}\text { Prevalence DVT } \\
\text { POCT D-di }\end{array}$ & $3.8 \%$ & $2.7 \%$ & $4.9 \%$ & Beta & $(12,24,46)$ \\
\hline & $\begin{array}{l}\text { Sensitivity POCT } \\
\text { D-di }\end{array}$ & $93.2 \%$ & $68.0 \%$ & $100.0 \%$ & Beta & $(12,24,46)$ \\
\hline
\end{tabular}


Table 2: Model input parameters for strategies used, showing the parameter, the value (probability) used in the model, the $95 \% \mathrm{Cl}$ interval, the distribution used and the data source.

\begin{tabular}{|c|c|c|c|c|c|c|}
\hline & $\begin{array}{l}\text { Specificity POCT } \\
\text { D-di }\end{array}$ & $68.6 \%$ & $59.3 \%$ & $77.9 \%$ & Beta & $(12,24,46)$ \\
\hline & $\begin{array}{l}\text { Prevalence DVT } \\
\text { CUS after POCT D- } \\
\text { dim }\end{array}$ & $10.5 \%$ & $0.1 \%$ & $20.8 \%$ & Beta & $(12,24,46)$ \\
\hline & $\begin{array}{l}\text { Sensitivity POCT } \\
\text { CUS after POCT D- } \\
\text { dim }\end{array}$ & $93.8 \%$ & $68.7 \%$ & $100.0 \%$ & Beta & $(12,24,46)$ \\
\hline & $\begin{array}{l}\text { Specificity POCT } \\
\text { CUS after POCT D- } \\
\text { dim }\end{array}$ & $97.8 \%$ & $92.6 \%$ & $100.0 \%$ & Beta & $(12,24,46)$ \\
\hline & $\begin{array}{l}\text { Prevalence CUS } \\
\text { after }>4 \text { CDR }\end{array}$ & $31.5 \%$ & $28.4 \%$ & $34.7 \%$ & Beta & $(12,24,46)$ \\
\hline & $\begin{array}{l}\text { Sensitivity CUS } \\
\text { after }>4 \text { CDR }\end{array}$ & $93.8 \%$ & $69.5 \%$ & $100.0 \%$ & Beta & $(12,24,46)$ \\
\hline & $\begin{array}{l}\text { Specificity CUS } \\
\text { after }>4 \text { CDR }\end{array}$ & $97.8 \%$ & $94.9 \%$ & $100.0 \%$ & Beta & $(12,24,46)$ \\
\hline Complications & PE & $27.0 \%$ & $13.6 \%$ & $40.4 \%$ & Beta & $(47)$ \\
\hline & PTS & $6.0 \%$ & $3.1 \%$ & $9.0 \%$ & Beta & $(50)$ \\
\hline & Major Bleeding & $3.5 \%$ & $1.8 \%$ & $5.2 \%$ & Beta & $(44,51)$ \\
\hline & Recurrence & $5.0 \%$ & $2.6 \%$ & $7.5 \%$ & Beta & $(52)$ \\
\hline
\end{tabular}

DVT = Deep venous thrombosis, CDR = Clinical Decision Rule, CUS = Compression Ultrasonography, D-di = D-dimer assay, GP = General practitioner, $\mathrm{POCT}=$ Point-of-care Test, $\mathrm{PE}=$ Pulmonary Embolism, $\mathrm{PTS}=$ Post Thrombotic Syndrome. 
Table 3

Model input parameters for costs, showing the parameter, the value (amount) used in the model, the $95 \%$ $\mathrm{Cl}$ interval, the distribution used and the data source.

\begin{tabular}{|c|c|c|c|c|c|c|}
\hline $\begin{array}{l}\text { Cost } \\
\text { parameters }\end{array}$ & Category & Cost & $\begin{array}{l}\text { Lower } \\
\text { limit } \\
95 \% \mathrm{Cl}\end{array}$ & $\begin{array}{l}\text { Upper } \\
\text { limit 95\% } \\
\text { Cl }\end{array}$ & $\begin{array}{l}\text { Distri- } \\
\text { bution }\end{array}$ & Refer-ence \\
\hline \multirow[t]{2}{*}{ Consultation } & $\begin{array}{l}\text { Appointment at } \\
\text { GP practice }\end{array}$ & $€ 36.45$ & $€ 18.60$ & $€ 54.32$ & Gamma & (35) \\
\hline & $\begin{array}{l}\text { Consult by } \\
\text { phone }\end{array}$ & $€ 18.78$ & $€ 9.58$ & $€ 27.98$ & Gamma & (35) \\
\hline \multirow[t]{5}{*}{ Diagnostics } & Blood draw & $€ 6.30$ & $€ 3.21$ & $€ 9.39$ & Gamma & $(20)$ \\
\hline & $\begin{array}{l}\text { D-di POCT at } \\
\text { office (fast- } \\
\text { POCT strategy) }\end{array}$ & $€ 32.83$ & $€ 16.74$ & $€ 48.90$ & Gamma & Company info \\
\hline & $\begin{array}{l}\text { D-di POCT } \\
\text { including AQT } \\
\text { (DVT care } \\
\text { pathway) }\end{array}$ & $€ 8.83$ & $€ 4.50$ & $€ 13.15$ & Gamma & Company info \\
\hline & $\begin{array}{l}\text { D-di assay on } \\
\text { STA-Liatest }\end{array}$ & $€ 5.81$ & $€ 2.96$ & $€ 8.65$ & Gamma & $(20)$ \\
\hline & CUS & $€ 92.19$ & $€ 47.02$ & $€ 137.37$ & Gamma & $(20)$ \\
\hline \multirow[t]{2}{*}{ Travel } & To GP & $€ 0.23$ & $€ 0.11$ & $€ 0.34$ & Gamma & (35) \\
\hline & $\begin{array}{l}\text { To phlebotomy } \\
\text { service }\end{array}$ & $€ 4.79$ & $€ 2.44$ & $€ 7.13$ & Gamma & (35) \\
\hline Treatment & $\begin{array}{l}\text { Treatment } \\
\text { costs }\end{array}$ & $\begin{array}{l}€ \\
580.79\end{array}$ & $\begin{array}{l}€ \\
269.20\end{array}$ & $€ 865.37$ & Gamma & $(20,38,39,41)$ \\
\hline \multirow[t]{4}{*}{ Complication } & Cost PE & $\begin{array}{l}€ \\
4,501.04\end{array}$ & $\begin{array}{l}€ \\
2,259.53\end{array}$ & $\begin{array}{l}€ \\
6,706.54\end{array}$ & Gamma & $(20,38,39,41,43)$ \\
\hline & Cost PTS & $\begin{array}{l}€ \\
4,001.12\end{array}$ & $\begin{array}{l}€ \\
2,040.57\end{array}$ & $\begin{array}{l}€ \\
5,961.67\end{array}$ & Gamma & $(20,41,43)$ \\
\hline & $\begin{array}{l}\text { Cost major } \\
\text { bleeding }\end{array}$ & $€_{7,174.99}$ & $\begin{array}{l}€ \\
3,659.25\end{array}$ & $\begin{array}{l}€ \\
10,690.73\end{array}$ & Gamma & $(20,38,39,41,43)$ \\
\hline & Cost recurrence & $\begin{array}{l}€ \\
673.78\end{array}$ & $\begin{array}{l}€ \\
346.38\end{array}$ & $\begin{array}{l}€ \\
1,012.87\end{array}$ & Gamma & $(20,38,39,41)$ \\
\hline \multirow{2}{*}{$\begin{array}{l}\text { Male } \\
\text { productivity } \\
\text { costs per hour }\end{array}$} & $<34$ & $€ 30.61$ & $€ 15.61$ & $€ 45.61$ & Gamma & (17) \\
\hline & $35-44$ & $€ 37.25$ & $€ 19.00$ & $€ 55.50$ & Gamma & (17) \\
\hline
\end{tabular}

DVT = Deep venous thrombosis, CUS = Compression Ultrasonography, D-di = D-dimer assay, GP = General practitioner, $\mathrm{POCT}=$ Point-of-care Test, $\mathrm{PE}=$ Pulmonary Embolism, PTS $=$ Post Thrombotic Syndrome. 


\begin{tabular}{|c|c|c|c|c|c|c|}
\hline $\begin{array}{l}\text { Cost } \\
\text { parameters }\end{array}$ & Category & Cost & $\begin{array}{l}\text { Lower } \\
\text { limit } \\
95 \% \mathrm{Cl}\end{array}$ & $\begin{array}{l}\text { Upper } \\
\text { limit 95\% } \\
\text { Cl }\end{array}$ & $\begin{array}{l}\text { Distri- } \\
\text { bution }\end{array}$ & Refer-ence \\
\hline & $45-54$ & $€ 37.16$ & $€ 18.97$ & $€ 55.38$ & Gamma & $(17)$ \\
\hline & $55-64$ & $€ 32.88$ & $€ 16.76$ & $€ 48.99$ & Gamma & $(17)$ \\
\hline & $65-75$ & $€ 7.49$ & $€ 3.82$ & $€ 11.16$ & Gamma & $(17)$ \\
\hline & $>75$ & $€ 2.08$ & $€ 1.06$ & $€ 3.10$ & Gamma & (17) \\
\hline \multirow{6}{*}{$\begin{array}{l}\text { Female } \\
\text { productivity } \\
\text { costs per hour }\end{array}$} & $<34$ & $€ 27.57$ & $€ 14.06$ & $€ 41.08$ & Gamma & $(17)$ \\
\hline & $35-44$ & $€ 30.56$ & $€ 15.59$ & $€ 45.55$ & Gamma & (17) \\
\hline & $45-54$ & $€ 30.34$ & $€ 15.47$ & $€ 45.21$ & Gamma & (17) \\
\hline & $55-64$ & $€ 23.81$ & $€ 12.14$ & $€ 35.48$ & Gamma & (17) \\
\hline & $65-75$ & $€ 3.47$ & $€ 1.77$ & $€ 5.17$ & Gamma & (17) \\
\hline & $>75$ & $€ 0.76$ & $€ 0.39$ & $€ 1.13$ & Gamma & (17) \\
\hline
\end{tabular}

Table 4

Model input parameters for quality of life, showing the parameter, the value (utility) used in the model, the $95 \% \mathrm{Cl}$ interval, the distribution used and the data source.

\begin{tabular}{|lllllll|}
\hline $\begin{array}{l}\text { Quality of life } \\
\text { estimates }\end{array}$ & Category & Utility & $\begin{array}{l}\text { Lower } \\
\text { limit 95\% } \\
\text { Cl }\end{array}$ & $\begin{array}{l}\text { Upper } \\
\text { limit 95\% } \\
\text { Cl }\end{array}$ & $\begin{array}{l}\text { Distri- } \\
\text { bution }\end{array}$ & $\begin{array}{l}\text { Refer- } \\
\text { ence }\end{array}$ \\
\hline $\begin{array}{l}\text { Average quality of } \\
\text { life in 6 months }\end{array}$ & Healthy & 0.4345 & 0.2163 & 0.5 & Beta & $(34)$ \\
\cline { 2 - 6 } & Treated DVT & 0.3924 & 0.1961 & 0.5 & Beta & $(5,31)$ \\
\hline $\begin{array}{l}\text { DVT with PE } \\
\text { DVT with PTS }\end{array}$ & 0.3880 & 0.1940 & 0.5 & Beta & $(5,31,33)$ \\
\hline $\begin{array}{l}\text { DVT with major } \\
\text { bleeding }\end{array}$ & 0.3874 & 0.1937 & 0.5 & Beta & $(5,31,44)$ \\
\hline $\begin{array}{l}\text { DVT with } \\
\text { recurrence }\end{array}$ & 0.3762 & 0.1883 & 0.5 & Beta & $(5,31)$ \\
\hline DVT = Deep venous thrombosis, PE = Pulmonary Embolism, PTS = Post Thrombotic Syndrome. \\
\hline
\end{tabular}

\section{Probabilistic sensitivity analysis}

A probabilistic sensitivity analysis (PSA) was performed by means of a Monte Carlo simulation $(10,000$ iterations of from 10,000 patients) to demonstrate the effect of joint uncertainty in the input parameters 
on the outcomes of the model. An incremental cost-effectiveness plane was used to display the uncertainty in model outcomes.

\section{One-way sensitivity analysis}

A one-way sensitivity analysis was performed to determine which parameters substantially influence model outcomes. The impact on the output of each strategy was analyzed by applying the lower and upper limit of the corresponding $95 \%$ confidence intervals (Cls) of each parameter in the model. Results are presented in tornado diagrams.

\section{Results}

The average costs per patient were $€ 827$ (95\% Cl: $€ 750-909)$ for the regular strategy, $€ 724$ (95\% Cl: $€ 656-$ 798) for the DVT care pathway, and $€ 740$ (95\% Cl: €674-812) for the fast-POCT strategy. Average costsavings for the DVT care pathway and for the fast-POCT strategy compared with the regular strategy were $€ 103 /$ patient (95\% Cl: $-€ 117-89$, a relative reduction of $12.4 \%)$ and $€$ 87/patient (95\% Cl: $-€ 113-63$, a relative decrease of $10.5 \%$ ), respectively. As the difference in QALYs was approximately -0.0002 , equal to less than two hours in full health, this was considered clinically irrelevant. Therefore, no ICER was determined, as the ICER would be unstable with this low denominator. The use of the DVT care pathway instead of the regular strategy could result in health care savings of approximately $€ 2,575,000$ halfyearly ( $€ 103 * 25,000$ patients), thus $€ 5,150,000$ annually. The fast-POCT strategy could save approximately $€ 2,175,000$ half-yearly ( $€ 87$ * 25,000 patients), $€ 4,350,000$ annually.

(Separate file) Figure 2a: Incremental cost-effectiveness plane of the DVT care pathway versus the regular strategy.

(Separate file) Figure 2b: Incremental cost-effectiveness plane of the fast-POCT strategy versus the regular strategy.

Figures $2 \mathrm{a}$ and $2 \mathrm{~b}$ show an incremental cost-effectiveness plane, presenting the results of the PSA. These figures show cost savings of $100 \%$ when comparing the DVT care pathway and the fast-POCT strategy to the regular strategy.

(Separate file) Figure 3a: Tornado diagram showing the impact of varying input parameters on model outcome when the regular strategy is compared to the DVT care pathway. CUS: compression ultrasonography. POCT: point-of-care. CDR: clinical decision rule.

(Separate file) Figure 3b: Tornado diagram showing the impact of varying input parameters on model outcome when the regular strategy is compared to the fast-POCT strategy. DVT: deep vein thrombosis. CUS: compression ultrasonography. POCT: point-of-care. CDR: clinical decision rule.

The tornado diagrams shown in figure $3 \mathrm{a}$ and $3 \mathrm{~b}$ demonstrate the influence of the uncertainties of the input parameters on the incremental costs. Comparing the DVT care pathway and the fast-POCT strategy 
to the regular strategy shows the time of arrival of patients has the greatest impact on the differences in costs, as more patients are referred directly to undergo a CUS. All outcomes of the univariate sensitivity analyses show that the DVT care pathway and the fast-POCT strategy result in cost-savings compared to the regular strategy.

An additional sensitivity analysis was performed to determine the extent of influence of arrival time of patients at the GP practice on the outcome of the model. Table 5 shows that the arrival time did not influence model outcomes.

Table 5

Additional sensitivity analysis for arrival time parameter

\begin{tabular}{|lll|}
\hline $\begin{array}{l}\text { Probability patient } \\
\text { arriving in time (\%) }\end{array}$ & $\begin{array}{l}\text { Incremental costs regular strategy } \\
\text { vs. DVT care pathway (€) }\end{array}$ & $\begin{array}{l}\text { Incremental costs regular strategy } \\
\text { vs. fast-POCT strategy }(\boldsymbol{\epsilon})\end{array}$ \\
\hline 0.0 & 90.92 & 66.44 \\
\hline 70.8 & 65.49 & 33.81 \\
\hline 100.0 & 54.52 & 30.04 \\
\hline
\end{tabular}

\section{Discussion}

We demonstrated that both POCT-based approaches in this study, if implemented, reduce costs from a societal perspective when compared to the regular strategy. The loss of QALYs ( $<0.0002$ QALYs loss over a 6-month time horizon) was considered not to be clinically relevant. In view of these results, using a POCT D-dimer test is the most advantageous option, despite the relatively high costs of POCT devices in terms of purchase and maintenance.

Data from the latest quantitative POCT devices were used in this study. These test systems are considered to be patient and user-friendly as they only require a capillary finger prick of blood, facilitating the application of these devices in settings outside the laboratory (16). More studies on this topic have been performed on past-generation POCT devices, but none, to our knowledge, have incorporated productivity losses per health state or fully considered production costs and complication losses as detailed as in our study. Neither have they incorporated alternative scenarios like the hybrid approach of a DVT care pathway, or sub-scenarios in which physicians do not follow current guidelines. Our results are in line with earlier studies on now-deprecated POCT devices which demonstrate that POCT-based approaches are less expensive than the regular strategy. $(41,43)$

In the near future, the rapid evolution of quantitative capillary POCT devices is expected to improve their diagnostic accuracy, further improving health-related outcomes. The false-negative rate is expected to be further reduced with fewer cases being missed. This will lead to a decline of complications in the DVT care pathway and fast-POCT strategy, compared to current model outcomes.

\section{Strengths}


The main strength of this study is that it was set up to provide an accurate and detailed illustration of diagnostic work-up after a patient with DVT symptoms presents to the GP. In order to achieve this, we incorporated two important real-life input parameters in our model. The first parameter is the estimated production cost loss per health state based on the literature. $(32,36,37,45)$ Net labor participation per complication and associated health-state, sex and age group were used to accurately represent production losses and related costs in real-life DVT patients in the 6-month time horizon during and after DVT diagnosis. The second parameter is the arrival time of patients at the GP as this can greatly affect the chosen diagnostic strategy. As these parameters have an impact on the costs, they form significant factors.

A further strength is the conservative assumptions made in the model regarding treatment costs, thus possibly underestimating cost savings. For example, treatment and complication costs were based on treatment for six months based on available data, even though only three months were suggested by the Dutch College of General Practitioners (7). Moreover, as the Sn and Sp of the current POC test devices are lower than their conventional counterparts, more complications were found in the POCT-based approaches. Furthermore, the diagnostic performance of D-dimer POC tests is expected to improve in the near future, so current assumptions about their diagnostic values will probably underestimate the costsavings of POCT-based strategies. Combining these factors, we expect further cost savings and health losses using the POCT-based approaches. Furthermore, in our model we assumed that a POC test at the GP practice would lead to a more time-consuming consultation in the fast-POCT strategy. However, if this test could embedded in the first consultation, this would reduce consultation costs, resulting in additional cost-savings when using the fast-POCT strategy.

\section{Limitations}

Several limitations need to be addressed. First, some input parameters used in the model were obtained from the literature, while others were based on assumptions. One of these assumptions is the time of arrival at the GP of a patient experiencing symptoms that could indicate a DVT. There is no specific data available on how many patients arrive too late for the GP to obtain laboratory D-dimer results before the end of the working day. This is relevant as the follow-up cannot be done on the same day. Because of this, arrival time greatly affects the GP's strategy so we chose to include this variable in our model. We performed a scenario analysis in which all patients arrived on time vs. another scenario in which they were directly referred to undergo a CUS. This analysis showed no substantial change in model outcomes. Therefore, it is unlikely that this limitation has affected our conclusions.

A second limitation is that a full cost-effectiveness study could not be performed due to the small differences in QALYs between the three different strategies. These can be explained by the small difference in Sn and Sp between the laboratory and POCT-based D-dimer assays. Instead, we performed a cost-minimization analysis, which provided insights into the considerable cost savings of the POCTbased approaches.

\section{Implications for practice}


Patient-friendliness is an important factor in health care. We were unable to include patient-friendliness in our model, as no quantitative measures are currently available for this item. However, waiting time can be reduced, resulting from (i) a POCT assay being performed during the GP consultation in the fast-POCT strategy and (ii) direct referral to the radiologist and internist in the DVT care pathway. These both substantially contribute to patient-friendliness. Furthermore, once the consultation is completed in the two POCT-based approaches, GPs are no longer responsible for follow-up of their patients, so this will also reduce the risk of errors.

We show that both the DVT care pathway and the fast-POCT strategy save costs when compared to the regular strategy. If a final choice between these two strategies has to be made, the size and location of the GP practice should be taken into consideration. Larger practices in remote areas may benefit more from the fast-POCT strategy as the majority of (mostly negative-D-dimer) patients will not be referred; this would greatly reduce their travel time. Moreover, costs per patient per test are limited as POCT device procurement costs can be spread over more patients. For the same reason, smaller practices may benefit more from the DVT care pathway.

\section{Conclusions}

In conclusion, both POCT-based approaches showed cost-savings, with a negligible loss of QALYS compared to the most common current strategy. We are convinced that with the demonstrated cost savings and the added patient and user-friendliness, the DVT care pathway and the fast-POCT strategy should be introduced in clinical practice.

\section{Abbreviations}

DVT

Deep vein thrombosis

PE

Pulmonary embolism

PTS

Post-thrombotic syndrome

GP

General practitioner

CDR

Clinical decision rule

CUS

Compression ultrasonography

Sn

Sensitivity

Sp

Specificity 
POCT

Point-of-care test

QALY

Quality-adjusted life years

ICER

Incremental cost-effectiveness ratio

PSA

Probabilistic sensitivity analysis

\section{Declarations}

\section{Ethics approval and consent to participate}

All methods were performed in accordance with the relevant guidelines and regulations. 'Consent to participate' is not applicable, as no patient level data was included in this study.

\section{Consent for publication}

Not applicable.

\section{Availability of data and materials}

All data generated or analyzed during this study are included in this published article and its supplementary files.

\section{Competing interests}

The authors declare that they have no competing interests.

\section{Funding}

This study was performed without financial aid of (non-)profit organizations.

\section{Author's contributions}

MK, JH, JN and RK were involved in final study design. JN and MK were involved in data acquisition and model analysis. JN and $\mathrm{JH}$ wrote the first draft of the manuscript. All authors have reviewed and edited the manuscript and approved the final version.

\section{Acknowledgements}

Not applicable.

\section{References}


1. Scheres LJJ, Lijfering WM, Cannegieter SC. Current and future burden of venous thrombosis: Not simply predictable. Res Pract Thromb Haemost. 2018;2(2):199-208.

2. Tagalakis V, Patenaude V, Kahn SR, Suissa S. Incidence of and Mortality from Venous Thromboembolism in a Real-world Population: The Q-VTE Study Cohort. Am J Med [Internet]. 2013;126(9):832.e13-832.e21. Available from: http://dx.doi.org/10.1016/j.amjmed.2013.02.024

3. Rabinovich A, Kahn SR. The postthrombotic syndrome: current evidence and future challenges. $J$ Thromb Haemost. 2017;15:230-41.

4. Prandoni P, Lensing AWA, Piccioli A, Bernardi E, Simioni P, Girolami B, et al. Recurrent Venous Thromboembolism and Bleeding Complications During Anticoagulant Treatment in Patients with Cancer and Venous Thromboembolism. Clin Obs Interv Ther Trials [Internet]. 2002;100(10):3484-8. Available from: https://www.mendeley.com/catalog/identification-specific-inhibitor-histonemethyltransferase-suvar39-2/

5. Hsiang L, Alexander C, Giancarlo TC, Pearl A, Rupert DG. Comparison of quality of life measurements: EQ-5D-5L versus disease / treatment-specific measures in pulmonary embolism and deep vein thrombosis. Qual Life Res [Internet]. 2019;28(5):1155-77. Available from: http://dx.doi.org/10.1007/s11136-018-2081-3

6. Monreal M, Agnelli G, Chuang LH, Cohen AT, Gumbs PD, Bauersachs R, et al. Deep Vein Thrombosis in Europe-Health-Related Quality of Life and Mortality. Clin Appl Thromb. 2019;25.

7. Nederlands Huisartsen Genootschap. NHG-Standaard Diepe veneuze trombose en longembolie [Internet]. 2017 [cited 2020 Mar 3]. Available from: https://www.nhg.org/standaarden/volledig/nhgstandaard-diepe-veneuze-trombose-en-longembolie

8. Büller HR, Cate-Hoek AJT, Hoes AW, Joore MA, Moons KGM, Oudega R, et al. Safely ruling out deep venous thrombosis in primary care. Ann Intern Med. 2009;150(4):229-35.

9. Geersing GJ, Erkens PMG, Lucassen WAM, Büller HR, Ten Cate H, Hoes AW, et al. Safe exclusion of pulmonary embolism using the Wells rule and qualitative D-dimer testing in Primary care: Prospective cohort study. BMJ. 2012;345(7880):1-10.

10. Toll DB, Oudega R, Bulten RJ, Hoes AW, Moons KGM. Excluding deep vein thrombosis Validation study of a simple diagnostic rule. J Fam Pract. 2006;55(7):613-8.

11. Van Maanen R, Kingma AEC, Oudega R, Rutten FH, Moons K, Geersing GJ. Real-life impact of clinical prediction rules for venous thromboembolism in primary care: A cross-sectional cohort study. BMJ Open. 2020;10(12):1-9.

12. Kingma AEC, Stel HF Van, Oudega R, Moons KGM, Geersing G. Multi-faceted implementation strategy to increase use of a clinical guideline for the diagnosis of deep venous thrombosis in primary care. 2016;(1):1-6.

13. Lucassen W, Geersing G, Erkens PMG, Reitsma JB, Moons KGM, Bu H, et al. Clinical Decision Rules for Excluding Pulmonary Embolism: A Meta-analysis. Ann Intern Med. 2011;155:448-60.

14. Geersing G, Janssen KJ, Oudega R, Weert H Van, Stoffers H. Diagnostic classification in patients with suspected deep venous thrombosis: physicians' judgement or a decision rule? Br J Gen Pract. 
2010;742-8.

15. Bakx P, O'Donnell O, van Doorslaer E. Spending on Health Care in the Netherlands: Not Going So Dutch. Fisc Stud. 2016;37(3-4):593-625.

16. Heerink JS, Gemen E, Oudega R, Hopstaken R, Geersing J, Kusters R. Analytical performance and user-friendliness of five novel point-of-care D-dimer assays. Scand J Clin Lab Invest. 2020 Sep;80(5):433-440.

17. Centraal Bureau voor de Statistiek. Labour participation; key figures. 2021.

18. Oudega R, Moons KGM, Hoes AW. Ruling out deep venous thrombosis in primary care. A simple diagnostic algorithm including D-dimer testing. Thromb Haemost. 2005;94(1):200-5.

19. Parry BA, Chang AM, Schellong SM, House SL, Fermann GJ, Deadmon EK, et al. International, multicenter evaluation of a new D-dimer assay for the exclusion of venous thromboembolism using standard and age-adjusted cut-offs. Thromb Res. 2018;166(March):63-70.

20. Nederlandse Zorgautoriteit. Open data van de Nederlandse Zorgautoriteit [Internet]. 2020 [cited 2020 Mar 18]. Available from: https://opendisdata.nl/

21. Batenburg RS, van der Velden LFJ. Aantal huisartsen en aantal FTE van huisartsen vanaf 2007 tot en met 2016. NIVEL. 2017;1-19.

22. De Staat van Volksgezondheid en Zorg. General Practiciner's contact: number of contacts per person. 2019.

23. Landelijke Huisartsen Vereniging. General Practicioner's care facts and figures. 2020.

24. Elferink RFMO, Loot AE, Klashorst CGJ Van De, Hulsebos-huygen M, Piersma-wichers M, Oudega R, et al. Clinical evaluation of eight different D-dimer tests for the exclusion of deep venous thrombosis in primary care patients of deep venous thrombosis in primary care patients. Scand J Clin Lab Invest. 2015;75:230-8.

25. Ghys T, Sint-lucas AZ, Verschraegen I, Brussel VU, Leus B, Jochmans K. Diagnostic accuracy of the Triage ${ }^{\circledR} \mathrm{D}$-dimer test for exclusion of venous thromboembolism in outpatients. Thromb Res. 2008;121:735-41.

26. Gibson NS, Schellong SM, Kheir DYE, Beyer-Westendorf J, Gallus AS, Mcrae S, et al. Safety and sensitivity of two ultrasound strategies in patients with clinically suspected deep venous thrombosis: A prospective management study. J Thromb Haemost. 2009;7(12):2035-41.

27. Pernod G, Wu H, De Maistre E, Lazarchick J, Kassis J, Aguilar C, et al. Validation of STA-Liatest D-Di assay for exclusion of pulmonary embolism according to the latest Clinical and Laboratory Standard Institute/Food and Drug Administration guideline. Results of a multicenter management study. Blood Coagul Fibrinolysis. 2017;28(3):254-60.

28. Lim W, Le Gal G, Bates SM, Righini M, Haramati LB, Lang E, et al. American Society of Hematology 2018 guidelines for management of venous thromboembolism: Diagnosis of venous thromboembolism. Blood Adv. 2018;2(22):3226-56. 
29. Verheul RJ, Reijnen R, Kruiswijk M, Ponjee GAE. Analytische en klinische vergelijking van de $2 e$ generatie Tina-quant D-dimeer test met zijn voorganger en de VIDAS. Ned Tijdschr voor Klin Chemie en Lab. 2013;38(3):164-8.

30. Song J, Kweon TD, Song Y, Lee EY, Kim SJ, Park R. Analytical and clinical performance of a new point of care LABGEOIB D-dimer test for diagnosis of venous thromboembolism. Ann Clin Lab Sci. 2014;44(3):254-61.

31. Monreal M, Agnelli G, Chuang LH, Cohen AT, Gumbs PD, Bauersachs R, et al. Deep Vein Thrombosis in Europe - Health- Related Quality of Life and Mortality. Clin Appl Thromb. 2019;25:1-12.

32. Willich SN, Chuang LH, van Hout B, Gumbs P, Jimenez D, Kroep S, et al. Pulmonary embolism in Europe - Burden of illness in relationship to healthcare resource utilization and return to work. Thromb Res. 2018;170(January):181-91.

33. Chuang LH, Gumbs P, van Hout B, Agnelli G, Kroep S, Monreal M, et al. Health-related quality of life and mortality in patients with pulmonary embolism: a prospective cohort study in seven European countries. Qual Life Res. 2019;28(8):2111-24.

34. Szende A, Janssen B, Cabasés J. Self-Reported Population Health: An International Perspective based on EQ-5D. PharmacoEconomics \& Outcomes News. 2014. 1-46 p.

35. Hakkaart-van Roijen L, Bouwmans-Frijters CAM, Swan Tan S. Handleiding voor kostenonderzoek; Methoden en standaard kostprijzen voor economische evaluaties in de gezondheidszorg. Inst Med Technol Assessment, Erasmus Univ Rotterdam. 2016;1-127.

36. Guanella R, Ducruet T, Johri M, Miron MJ, Roussin A, Desmarais S, et al. Economic burden and cost determinants of deep vein thrombosis during 2 years following diagnosis: A prospective evaluation. J Thromb Haemost. 2011;9(12):2397-405.

37. Alfieri A, Gazzeri R, Pircher M, Unterhuber V, Schwarz A. A prospective long-term study of return to work after nontraumatic nonaneurysmal subarachnoid hemorrhage. J Clin Neurosci. 2011;18(11):1478-80.

38. Jong LA De, Dvortsin E, Janssen KJ, Postma MJ. Cost-effectiveness Analysis for Apixaban in the Acute Treatment and Prevention of Venous Thromboembolism in the Netherlands. Clin Ther [Internet]. 2017;39(2):288-302. Available from: http://dx.doi.org/10.1016/j.clinthera.2016.12.012

39. Leent MWJ Van, Stevanovi J, Jansman FG, Beinema MJ. Cost-Effectiveness of Dabigatran Compared to Vitamin-K Antagonists for the Treatment of Deep Venous Thrombosis in the Netherlands Using Real-World Data. PLoS One. 2015;1-15.

40. Ten Cate-Hoek AJ, Toll DB, Büller HR, Hoes AW, Moons KGM, Oudega R, et al. Cost-effectiveness of ruling out deep venous thrombosis in primary care versus care as usual. J Thromb Haemost. 2009;7(12):2042-9.

41. Hendriksen JM, Geersing GJ, Van Voorthuizen SC, Oudega R, Ten Cate-Hoek AJ, Joore MA, et al. The cost-effectiveness of point-of-care D-dimer tests compared with a laboratory test to rule out deep venous thrombosis in primary care. Expert Rev Mol Diagn. 2015;15(1):125-36. 
42. Centraal Bureau voor de Statistiek. Consumentenprijzen_prijsindex_2015_100_07042020_151716 [Internet]. 2020 [cited 2020 Mar 20]. Available from: https://opendata.cbs.nl/statline/\#/CBS/nl/dataset/83131ned/table?fromstatweb

43. Ten Cate-Hoek AJ, Toll DB, Büller HR, Hoes AW, Moons KGM, Oudega R, et al. Cost-effectiveness of ruling out deep venous thrombosis in primary care versus care as usual. J Thromb Haemost. 2009;7(12):2042-9.

44. Nieto JA, Solano R, Ruiz-Ribó MD, Ruiz-Gimenez N, Prandoni P, Kearon C, et al. Fatal bleeding in patients receiving anticoagulant therapy for venous thromboembolism: Findings from the RIETE registry. J Thromb Haemost. 2010;8(6):1216-22.

45. Centraal Bureau voor de Statistiek. Net labor participation in the Netherlands [Internet]. 2020 [cited 2021 Jan 21]. Available from: https://opendata.cbs.nl/statline/\#/CBS/nl/dataset/82309NED/table? fromstatweb

46. Technologies $N$, Tools $D$. Ruling out deep venous thrombosis in primary care A simple diagnostic algorithm including D-dimer testing. Thromb Haemost. 2005;94:20020-5.

47. Büller HR, Cate-Hoek AJT, Hoes AW, Joore MA, Moons KGM, Oudega R, et al. Safely ruling out deep venous thrombosis in primary care. Ann Intern Med. 2009;150(4):229-35.

48. Parry BA, Chang AM, Schellong SM, House SL, Fermann GJ, Deadmon EK, et al. International, multicenter evaluation of a new D-dimer assay for the exclusion of venous thromboembolism using standard and age-adjusted cut-offs. Thromb Res. 2018;166(March):63-70.

49. Swan Tan S, Bouwmans-Frijters CAM, Hakkaart-van Roijen L. Handleiding voor kostenonderzoek: methoden en referentieprijzen voor economische evaluaties in de gezondheidszorg. Tijdschr voor gezondheidswetenschappen. 2012;90(6):367-72

50. Prandoni P, Anthonie WA, Lensing AW, Cogo A, Cuppini S, Villalta S, et al. The long-term clinical course of acute deep vein thrombosis. Ann Intern Med. 1996;125(1):1-7.

51. Kruger PC, Eikelboom JW, Douketis JD, Hankey GJ. Deep vein thrombosis: update on diagnosis and management. Med J Aust. 2019;210(11):516-24.

52. Boutitie F, Pinede L, Schulman S, Agnelli G, Raskob G, Julian J, et al. Influence of preceding length of anticoagulant treatment and initial presentation of venous thromboembolism on risk of recurrence after stopping treatment: Analysis of individual participants' data from seven trials. Bmj. 2011;342(7810):1-9.

\section{Figures}


Figure 1

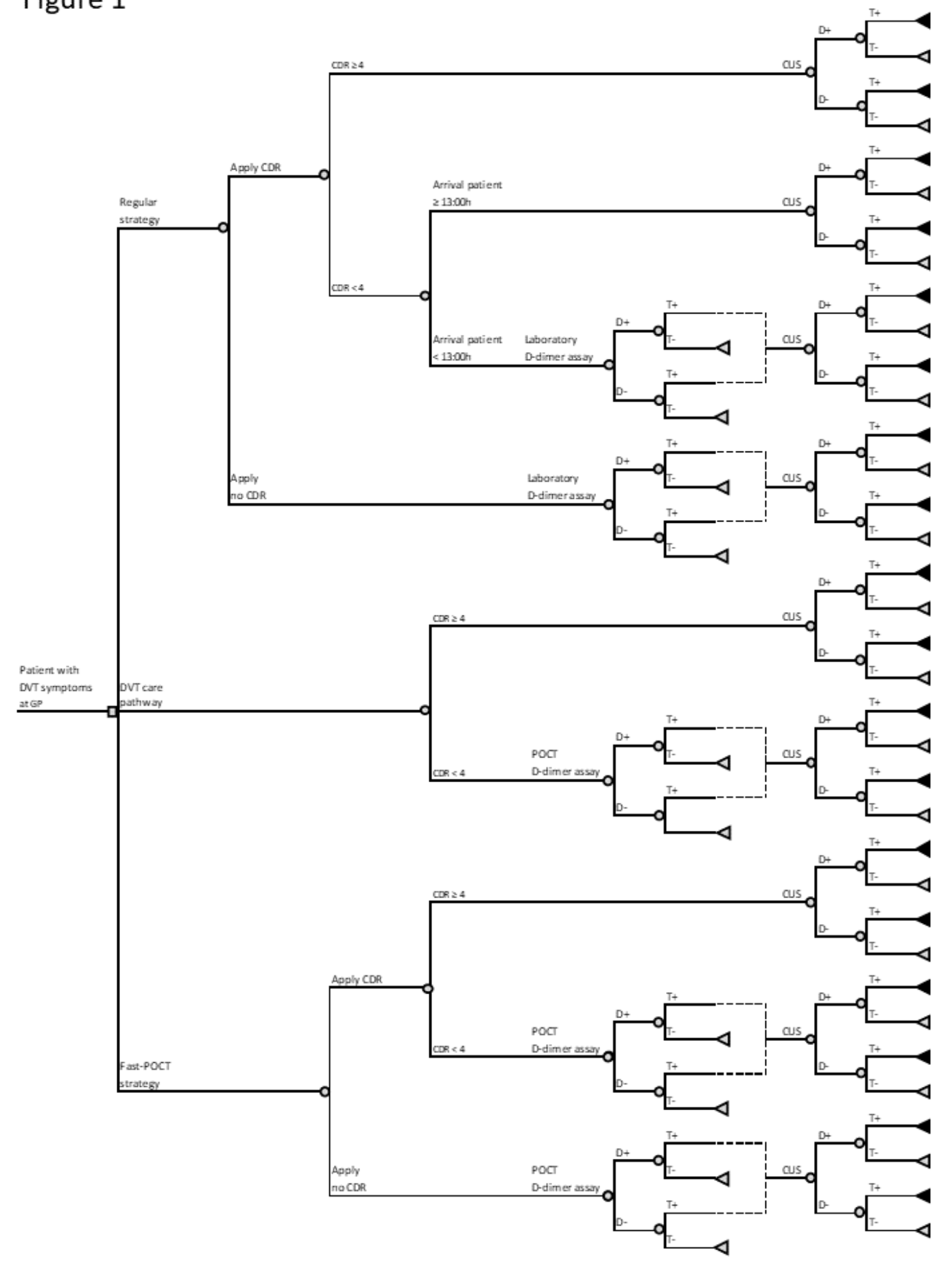

\section{Figure 1}

Schematic overview of diagnostic strategies of suspected deep venous thrombosis.

$C D R=$ clinical decision rule, CUS: compression ultrasonography, $D+=$ Disease present $D-=$ Disease absent, $D V T=$ Deep venous thrombosis, $G P=$ General practitioner, $P O C T=$ Point-of-care test,$T+=$ test with positive result after D-dimer assay or CUS, $T-=$ negative test result after D-dimer assay or CUS. 


\section{Figure 2}

2a: Incremental cost-effectiveness plane of the DVT care pathway versus the regular strategy.

2b: Incremental cost-effectiveness plane of the fast-POCT strategy versus the regular strategy.

\section{Figure 3}

3a: Tornado diagram showing the impact of varying input parameters on model outcome when the regular strategy is compared to the DVT care pathway. CUS: compression ultrasonography. POCT: pointof-care. CDR: clinical decision rule.

3b: Tornado diagram showing the impact of varying input parameters on model outcome when the regular strategy is compared to the fast-POCT strategy. DVT: deep vein thrombosis. CUS: compression ultrasonography. POCT: point-of-care. CDR: clinical decision rule.

\section{Supplementary Files}

This is a list of supplementary files associated with this preprint. Click to download.

- Supplementaryfile.docx 